\title{
Evaluation of an ELISA Method to Detect Listeria monocytogenes in Fresh-Cut Rocket
}

\author{
M. Cavaiuolo and A. Ferrante \\ Dept. Agricultural and \\ Environmental Sciences \\ Università degli Studi di Milano \\ Italy
}

\author{
G. Botticella, L. Beneduce and G. Spano \\ Dept. Science Agriculture, \\ Food \& Environment (SAFE) \\ University of Foggia \\ Italy
}

Keywords: contamination, microbial, vegetables, safety

\begin{abstract}
Leafy vegetables are consumed fresh after harvest with bland washes, not always efficient in removing pathogenic bacteria that may be attached to the external skin or surfaces. In this work, an optimized ELISA based method developed in our laboratory was used to detect the presence of Listeria monocytogenes in fresh-cut rocket leaves. From a certain quantity $(5 \mathrm{~g})$ of fresh rocket leaves contaminated with Listeria monocytogenes, bacteria were isolated and the pathogen was detected using an ELISA protocol. The preliminary results are promising in the use of antibody-antigen interaction to verify the presence of L. monocytogenes in the minimally processed vegetable distribution chain.
\end{abstract}

\section{INTRODUCTION}

Ready-to-eat (RTE) vegetables are minimally processed produce that are used for a direct consumption and do not undergo further washing or cooking. Ready-to-eat vegetables have a high potential risk of foodborne contaminations since most of them are processed in several ways from in-field packing to pre-cut and bagged product. Minimally processed leafy vegetables are usually grown in soil under plastic tunnel. The baby leaf production requires frequent soil preparation and the organic matter especially during summer rapidly declines. It means that manure or other organic substances have to be distributed in order to maintain the organic matter comprised between 1.5-3\%. By coming in contact with manure, leafy vegetables can be contaminated with pathogenic bacteria. The use of sewage irrigation water before harvest as well as inadequate or poor handling practices during preparation, processing and packing represent additional sources of microbial contamination (Cooley et al., 2006). Despite being washed with sanitizing agents, minimally processed leafy vegetables are consumed fresh and raw without thermal treatment and the risk of foodborne outbreak can occur. The UE regulation n. 2073/05 reports the safety criteria for different foods including ready-to-eat vegetables.

Among the human pathogenic bacteria, L. monocytogenes is an ubiquitous foodborne pathogen. It is a gram positive bacteria and the genus includes six species, but only the L. monocytogenes is pathogenic for the human. Therefore, it may contaminate a wide range of food commodities, especially fresh vegetables. L. monocytogenes can proliferate under antimicrobial conditions, i.e., low temperature, low water activity or low $\mathrm{pH}$ (Kovacevic et al., 2013). The growth potential of pathogens has been studied in nine ready-to-eat vegetables and the $L$. monocytogenes showed the highest values in wild rocket (Sant'Ana et al., 2012).

The identification of new reliable detection methods is always needed. Different methods have been tested to detect L. monocytogenes in different matrix, including immunoenzymatic assay, molecular biology approaches targeting both DNA or RNA and classical approaches based on selective enrichment and plating (Gasanov et al., 2005). The ready-to-eat leafy vegetables after preparation remain on the shelf of the market a period of time ranging from 3 to 5 days. In this food line, the detection methods should be very fast with the day-after result. Therefore, the aim of this work was to evaluate an ELISA assay that was optimized in our laboratory to reduce the detection time of L. monocytogenes in wild rocket fresh cut leaves. It does not want to substitute the current 
techniques but to improve and guarantee the safety for the consumers.

\section{MATERIAL AND METHODS}

\section{Plant Materials}

Rocket (Diplotaxis tenuifolia L.) was purchased from supermarkets in Foggia. Overnight bacterial culture was serially 10 -fold diluted and the dilutions were used to artificially contaminate rocket leaves. Spiking was realized by spraying cell suspension directly on the leaf tissue under class 2 bioharzard laminary flow cabinet, allowing to dry for $15 \mathrm{~min}$ under sterile air flow. Rocket samples of $5 \mathrm{~g}$ were homogenized in $10 \mathrm{ml}$ of $1 \times$

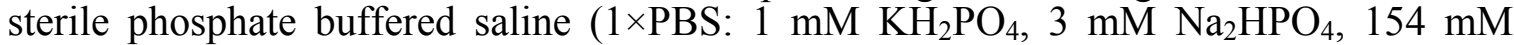
$\mathrm{NaCl}, \mathrm{pH} 7.2)$ under a laminar flow hood. Homogenized samples were incubated for $7 \mathrm{~h}$ at $30^{\circ} \mathrm{C}$ with agitation and centrifuged at $2000 \mathrm{rpm}$ for $20 \mathrm{~min}$ at room temperature. The pellet was suspended in $2 \mathrm{ml}$ of $1 \times \mathrm{PBS}$.

\section{Indirect Enzyme-Linked Immunosorbent Assay (ELISA)}

Primary antibody anti-Listeria monocytogenes (LZA2) (ab11439) and HRPconjugated secondary antibody (ab47827) were purchased from Abcam (Cambridge, UK) and used at concentration of $1 \mu \mathrm{g} / \mathrm{ml}$ and $400 \mathrm{ng} / \mathrm{ml}$ respectively. $100 \mu \mathrm{l}$ of the isolated L. monocytogenes bacteria were loaded overnight at $4{ }^{\circ} \mathrm{C}$ in the wells of an ELISA plate. After a four times washing step with $300 \mu \mathrm{l}$ of PBS-T (1× PBS, $0.05 \%$ Tween 20), wells were blocked with $100 \mu \mathrm{l}$ of $1 \%$ BSA PBS-T for maximum $2 \mathrm{~h}$ at $25^{\circ} \mathrm{C}$. After washing $100 \mu \mathrm{l}$ of primary antibody were incubated for $1 \mathrm{~h}$ followed by washing and incubation with $100 \mu \mathrm{l}$ of HRP-conjugated secondary antibody. After washing, $100 \mu \mathrm{l}$ of TMB solution were added for $45 \mathrm{~min}$ at $25^{\circ} \mathrm{C}$ in the dark and the reaction was stopped with an equal volume of $1 \mathrm{~N} \mathrm{HCl}$ or $2 \mathrm{~N} \mathrm{H}_{2} \mathrm{SO}_{4}$; the optical density (OD) was read at $450 \mathrm{~nm}$. An $\mathrm{OD}_{450 \mathrm{~nm}}$-fold change $\geq 2$ respect to a negative control (only PBS $1 \times$ buffer) was set as threshold to distinguish positive from negative samples.

\section{RESULTS AND DISCUSSION}

\section{Detection of Listeria monocytogenes}

Rocket leaves were inoculated with different concentrations of $L$. monocytogenes from $10^{0}$ to $10^{5}$ cells $/ \mathrm{g}$. The presence of this bacteria was verified with an indirect ELISA assay (Fig. 1). The antibody recognizes the outer membrane fraction and the whole cells of $L$. monocytogenes. A total of 6 samples were tested and all of them resulted positive for the presence of $L$. monocytogenes showing an $\mathrm{OD}_{450 \mathrm{~nm}}$-fold change $\geq 2$ (OD-fold= $\mathrm{OD}_{450 \mathrm{~nm}}$ sample $/ \mathrm{OD}_{450 \mathrm{~nm}}$ negative control). The negative control showed an $\mathrm{OD}_{450 \mathrm{~nm}}$ of 0.05 , while the contaminated samples had a value ranging from 0.14 to 0.2 (Fig. 2). With respect to the 4-5 days long microbiological methods that require a pathogens enrichment of at least $48 \mathrm{~h}$ (Welshimer, 1981), the results obtained from this ELISA-based method were accomplished in 24-28 h. Other interesting molecular techniques are those that use specific primers for mRNA or DNA of the L. monocytogenes. The advantage of this method that is sensitive and can be also very fast reducing the detection time to few hours. On the contrary often a specific extraction and isolation methods have to be developed for the different tissues. Moreover, the primers can also amplify the nucleic acid of dead bacteria with no dangerous effect on the consumer. In literature there is also information related to other ELISA methods that have been found to detect bacteria with threshold of $\geq 10^{5}$ cells $/ \mathrm{ml}$ with a time comprised from 40-48 h (Noah et al., 1991).

\section{CONCLUSIONS}

These preliminary results on rocket are promising in the use of specific antibodies to verify the presence of bacteria in a wide range of the minimally processed vegetables during the whole distribution chain. 


\section{ACKNOWLEDGEMENTS}

The research leading to these results has received funding from the European Union Seventh Framework Programme (FP7/2007-2013) under grant agreement n. 289719 (Project QUAFETY).

\section{Literature Cited}

Beuchat, L.R. 2006. Vectors and conditions for preharvest contamination of fruits and vegetables with pathogens capable of causing enteric diseases. British Food Journal 108(1):38-53.

Cooley, M.B., Chao, D. and Mandrell, R.E. 2006. Escherichia coli O157:H7 survival and growth on lettuce is altered by the presence of epiphytic bacteria. J Food Prot. 69(10):2329-2335.

Francis, G.A., Gallone, A., Nychas, G.J., Sofos, J.N., Colelli, G., Amodio, M.L. and Spano, G. 2012. Factors affecting quality and safety of fresh-cut produce. Crit. Rev. Food Sci. Nutr. 52(7):143.

Gasanov, U., Hughes, D. and Hansbro, P.M. 2005. Methods for the isolation and identification of Listeria spp. and Listeria monocytogenes: a review. FEMS Microbiol. Rev. 29:851-875.

Kovačević, M., Burazin, J., Pavlović, H., Kopjar, M. and Piližota, V. 2013. Prevalence and level of Listeria monocytogenes and other Listeria sp. in ready-to-eat minimally processed and refrigerated vegetables. World J. Microbiol. Biotechnol. 29(4):707-712.

Noah, C.W., Ramos, N.C. and Gipson, M.V. 1991. Efficiency of two commercial ELISA kits compared with the BAM culture method for detecting Listeria in naturally contaminated foods. J. Assoc. Off. Anal. Chem. 74:819-821.

Sant'Ana, A.S., Barbosa, M.S., Destro, M.T., Landgraf, M. and Franco, B.D. 2012. Growth potential of Salmonella spp. and Listeria monocytogenes in nine types of ready-to-eat vegetables stored at variable temperature conditions during shelf-life. Int. J. Food Microbiol. 157(1):52-58.

Welshimer, H.J. 1981. The genus Listeria and related organisms. p.1680-1687. In: M.P. Starr, H. Stolp, A. Truper, A. Balows and H.G. Schlegel (eds.), The Prokaryotes: A Springer, Berlin Handbook on Habitats, Isolation, and Identification of Bacteria. 


\section{Figures}

leaves infected with

L. monocytogenes
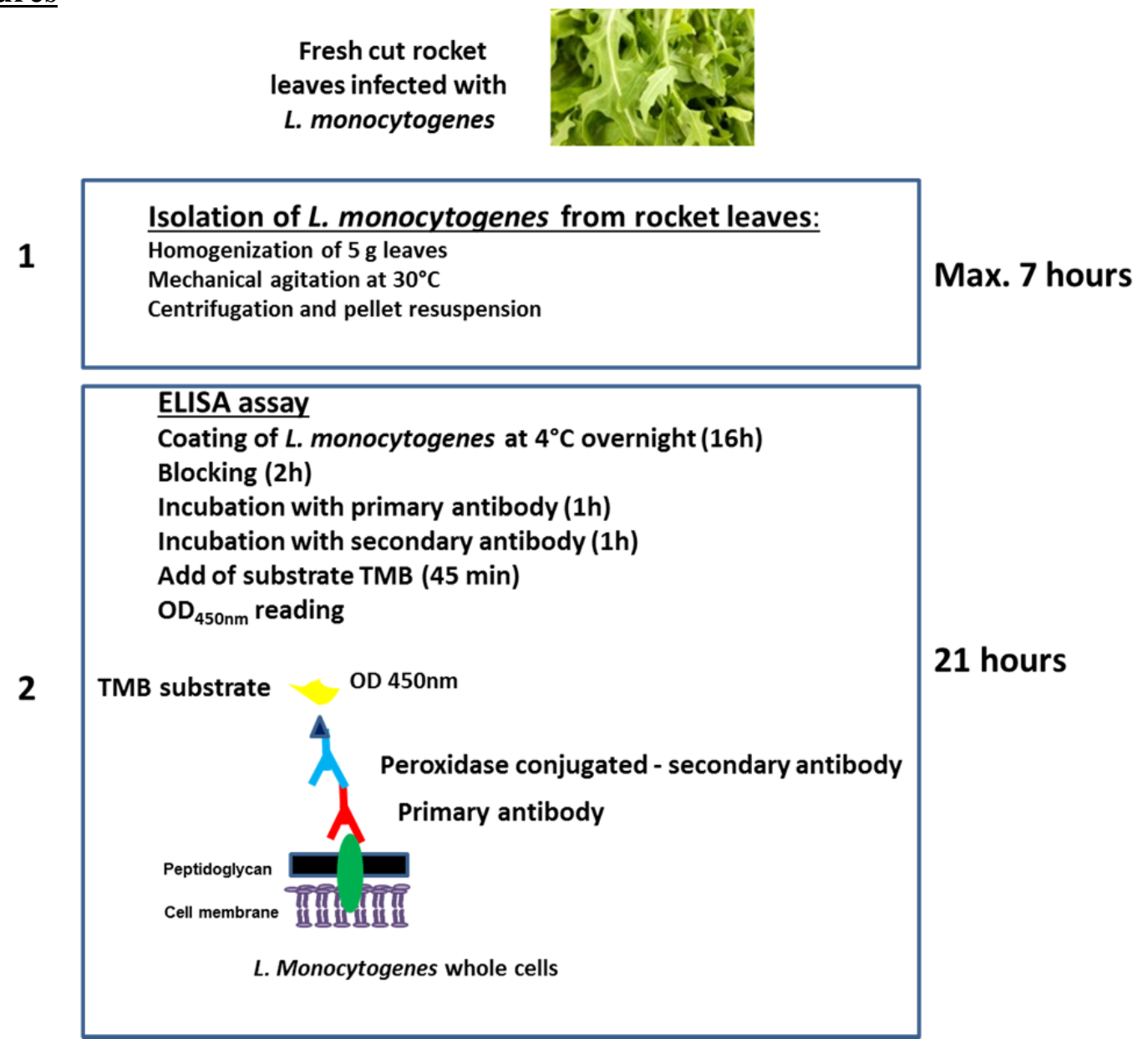

Fig. 1. Scheme of the ELISA protocol to detect L. monocytogenes in rocket leaves.

\section{Detection of $L$. monocytogenes in rocket leaves}

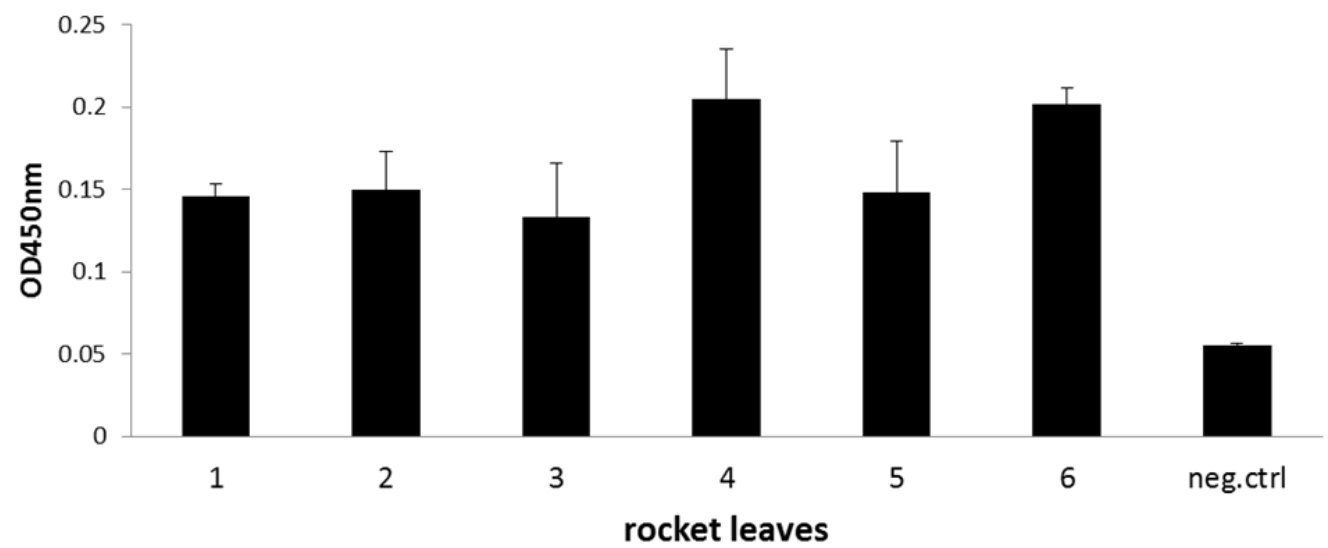

Fig. 2. Histograms showing samples versus $\mathrm{OD}_{450 \mathrm{~nm}}$ values. The value that showed a clear increment from the background was used to calculate the cut-off according to the following formula (Bioreba-ELISA Data analysis): mean of background values $+3 \mathrm{SD}$ of background values $+10 \%$. 